\title{
Calcification morphotypes of the coccolithophorid Emiliania huxleyi in the Southern Ocean: changes in 2001 to 2006 compared to historical data
}

\author{
J. C. Cubillos ${ }^{1}$, S. W. Wrightt ${ }^{2,3}$, G. Nash ${ }^{2}$, M. F. de Salas ${ }^{1}$, B. Griffiths ${ }^{3,4}$, \\ B. Tilbrook ${ }^{3,4}$, A. Poisson ${ }^{5}$, G. M. Hallegraeff ${ }^{1, *}$ \\ ${ }^{1}$ School of Plant Science, University of Tasmania, Private Bag 55, Hobart, Tasmania 7001, Australia \\ ${ }^{2}$ Australian Antarctic Division, Channel Highway, Kingston, Tasmania 7050, Australia \\ ${ }^{3}$ Antarctic Climate and Ecosystems Cooperative Research Centre, University of Tasmania, Private Bag 80, \\ Hobart, Tasmania 7001, Australia \\ ${ }^{4}$ Wealth from Oceans Flagship, CSIRO, GPO Box 1538, Hobart, Tasmania 7001, Australia \\ ${ }^{5}$ Laboratoire d'Océanographie et du Climat: Expérimentations et Approches Numériques, Université Pierre et Marie Curie, \\ 75252 Paris, France
}

\begin{abstract}
We conducted a scanning electron microscopic survey of morphological variations in the calcareous nanoplankton species Emiliania huxleyi in Southern Ocean surface water samples collected along a transect from 43 to $64^{\circ} \mathrm{S}$ and 141 to $145^{\circ} \mathrm{E}$ during November 2001, October to February 2002/2003, 2003/2004, 2004/2005 and 2005/2006. The results were compared with historical data from a similar transect occupied in December to January 1983/1984 and January to February 1994 and 1995. While E. huxleyi was absent or extremely sparse $\left(0.1\right.$ to 1 cells ml $\left.^{-1}\right)$ south of $60^{\circ} \mathrm{S}$ in 1983/1984 and 1994/1995, this species was consistently present at about $100 \mathrm{cells} \mathrm{m}^{-1}$ between 60 and $65^{\circ} \mathrm{S}$ during 2002 to 2006. The extended geographic range and/or increased southward abundance of this keystone species suggests a significant shift in Southern Ocean ecology over the past 2 decades, analogous to an observed recent range extension into the Bering Sea. Morphotype A 'overcalcified' mainly occurred north of the Subantarctic Front and was replaced by the weakly calcified Morphotype B/C between the Subantarctic Front and Southern Antarctic Circumpolar Current Front. This north-south shift in E. huxleyi calcification morphotypes closely tracked the north-south decline in the calcite saturation state as calculated from carbonate system measurements. Based on current evidence, no significant changes are apparent in the calcification status of $E$. huxleyi in the Southern Ocean during the past 12 yr. All cultured isolates from north of the Polar Front belonged to Morphotype A, while all strains isolated south of the Polar Front belonged to Morphotype B/C and their morphologies appeared conservative in culture. The north-south trend of decreased calcification of E. huxleyi in the Southern Ocean thus reflects the shift in dominance of one ecotype to another, rather than the environmental effect of decreased carbonatre ion concentrations and calcite saturation state on a single, 'apparently cosmopolitan', population.
\end{abstract}

KEY WORDS: Southern Ocean · Emiliania huxleyi $\cdot$ Calcite saturation state $\cdot$ Ocean acidification

\section{INTRODUCTION}

Approximately half of the anthropogenic $\mathrm{CO}_{2}$ released to the atmosphere since the beginning of the industrial revolution has dissolved in the ocean, leading to a reduction of surface $\mathrm{pH}$ by $0.1 \mathrm{U}$ (Riebesell et al. 2000, Orr et al. 2005). Under the IS92a scenario of continuing global $\mathrm{CO}_{2}$ emissions from human activities, the average $\mathrm{pH}$ of the upper ocean is predicted to fall by $0.4 \mathrm{U}$ to $\mathrm{pH} 7.8$ by the year 2100 . This $\mathrm{pH}$ is lower than has been experienced for millennia, and, critically, the predicted rate of change is 100 times 
faster than ever experienced in the known history of our planet (The Royal Society 2005). The effects of ocean acidification are additional to, and are likely to exacerbate, the effects of climate change, yet research into the biological effects of high concentrations of $\mathrm{CO}_{2}$ in the oceans is still in its infancy. It has been claimed that calcifying organisms will find it difficult to produce and maintain their calcareous shells. Of particular importance is the ubiquitous coccolithophorid nanoplankton Emiliania huxleyi that produces a shell (coccosphere) comprised of numerous calcite plates (coccoliths). Riebesell et al. (2000) experimentally simulated the effect of ocean acidification on a single North Atlantic strain (PML B92/11A; Morphotype A). Diminished calcification of E. huxleyi was accompanied by an increased proportion of malformed coccoliths and incomplete coccospheres. Extrapolation of these observations to the world's oceans raises the concern that ocean acidification will increase dissolution of calcium carbonate, causing a shift in the composition of the plankton community towards non-calcifying species. The Southern Ocean is particularly vulnerable due to a combination of low surface temperatures, which increase the solubility of $\mathrm{CO}_{2}$ and calcium carbonate, and the incidence of large amounts of upwelled deep water (Orr et al. 2005). Thus, predicted changes in Southern Ocean chemistry during this century are expected to have far-reaching effects in altering the trophic structure and biodiversity of these globally critical ecosystems.

Emiliania huxleyi first appeared in the geological record $270000 \mathrm{yr}$ ago and is now the dominant coccolithophorid in the world's oceans. This species is widely considered to be a ubiquitous cosmopolitan marine microalga, occurring from tropical to polar waters. Most of our knowledge on calcification in E. huxleyi, however, has derived from experimental research on predominantly North Atlantic culture strains (Paasche 2001). Some morphological variations have appeared stable in culture for many years under widely varying growth conditions and have been interpreted to be genotypic in nature (Young \& Westbroek 1991). The confirmation of immunological differences among Type A and B culture strains (Young \& Westbroek 1991) has corroborated these ideas. Genotypic variation has proved to be the strongest single influence on coccolith morphology. Currently, some 6 morphotypes are recognized (Young et al. 2003), based on the fine structure of their coccoliths, but their precise delimitation can be difficult. Other variations in the structure of the coccoliths have been interpreted to be due to incomplete or abnormal (teratological) growth, coccosphere cell size variation, and degree of calcification (the latter often correlated with temperature). In the present study, widespread concern about the potential effect of ocean acidification triggered a careful scanning electron microscopic analysis of E. huxleyi morphotypes in Southern Ocean samples collected from 43 to $64^{\circ} \mathrm{S}, 141$ to $145^{\circ} \mathrm{E}$, during November 2001 and October to February 2002/2003, 2003/2004, 2004/2005 and 2005/2006 and comparison with historic data from the same transect occupied from December to January 1983/1984 (Nishida 1986) and 1994/1995 (Findlay \& Giraudeau 2000).

\section{MATERIALS AND METHODS}

Field. The transect from Hobart $\left(44^{\circ} 57^{\prime} \mathrm{S}, 147^{\circ} 20^{\prime} \mathrm{E}\right)$ to the French base Dumont d'Urville in Terre Adélie, Antarctica $\left(65^{\circ} 50^{\prime} \mathrm{S}, 140^{\circ} 00^{\prime} \mathrm{E}\right)$, was sampled by the French MV 'l'Astrolabe' in 3 or 4 regular rotations per year from October to March in 2002/2003, 2003/2004, 2004/2005 and 2005/2006 (Fig. 1). Data from an earlier depth transect sampled by the Australian RV 'Aurora Australis' in November 2001 (Voyage 3) are also included. The positions of various frontal systems in the

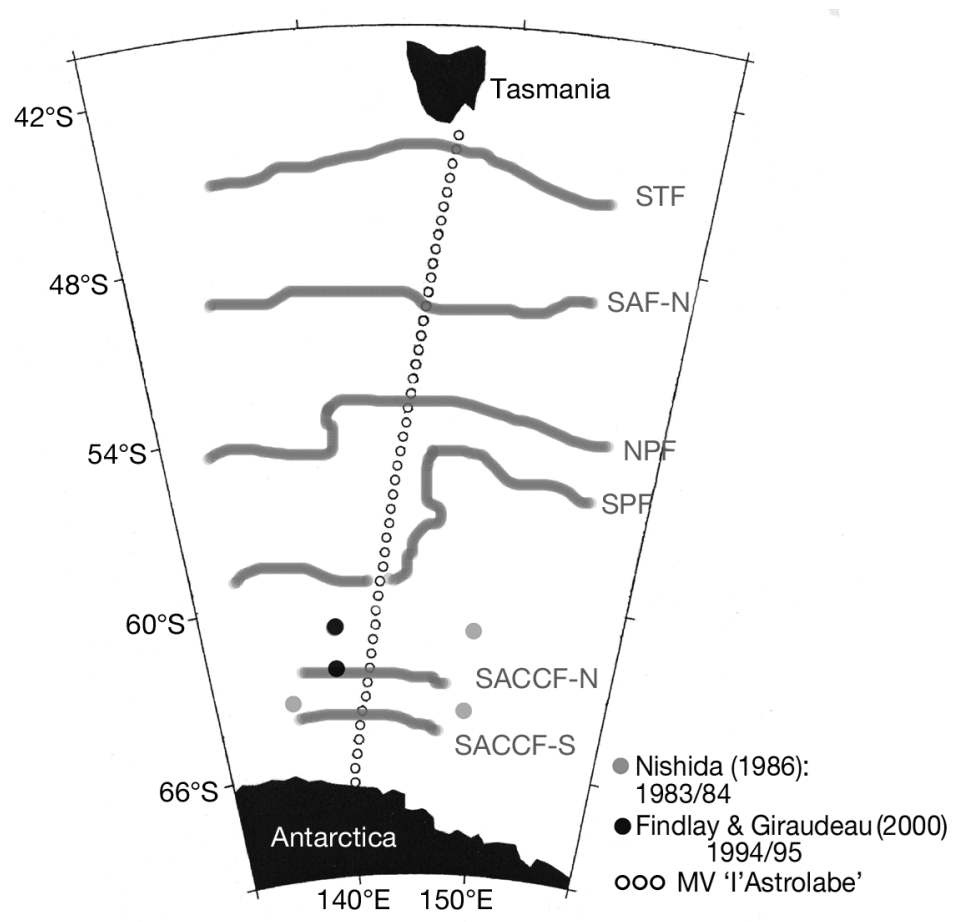

Fig. 1. Transect occupied by regular MV 'l'Astrolabe' voyages between Tasmania and Antarctica, showing key frontal systems: Subtropical Front (STF), Subantarctic Front, Northern branch (SAF-N), Northern Polar Front (NPF), Southern Polar Front (SPF), Southern Antarctic Circumpolar Current Front, Northern branch (SACCF-N) and Southern Antarctic Circumpolar Current Front, Southern branch (SACCF-S) (adapted from Sokolov \& Rintoul 2002). Southern Ocean stations south of $60^{\circ} \mathrm{S}$ previously occupied by Nishida (1986) in 1983/1984 and Findlay \& Giraudeau (2000) in 1994/1995 are indicated 
Southern Ocean were interpreted from thermosalinograph records using the water mass definitions of Sokolov \& Rintoul (2002). Carbonate ion and calcite saturation state were calculated using measurements of total dissolved inorganic carbon and titration alkalinity from Tilbrook et al. (2001). On board the MV 'l'Astrolabe', water samples were collected every 8 to $12 \mathrm{~h}$ from the clean water line, which constantly pumps subsurface water (3 $\mathrm{m}$ depth) into the vessel. On the RV 'Aurora Australis', samples from different depths were collected with 101 Niskin bottles mounted on a rosette sampler. Subsamples of $250 \mathrm{ml}$ were filtered through a $25 \mathrm{~mm}$ diameter Nuclepore membrane filter $(1 \mu \mathrm{m}$ pore size). Salt crystals were removed from the filter by rinsing twice with $1 \mathrm{ml}$ of distilled water, and the filters were gently air-dried and stored over silica gel.

Laboratory. Filters were prepared for scanning electron microscopy (SEM) by mounting onto a $1.2 \mathrm{~cm}$ diameter metal stub and sputter coating with $15 \mathrm{~nm}$ gold. Samples were examined using a JEOL 840 scanning electron microscope. A fixed magnification $(1500 \times)$ was used for all quantitative observations, with higher magnification for morphotype identification. Only cells of Emiliania huxleyi were counted, but the presence of other species of coccolithophorids was recorded, as well as the abundance of other phytoplankton groups. For each sample, 200 cells were counted and classified into morphotypes, unless cell concentrations were too low, in which case 2000 fields of view in transects across the filter were observed. Quantitative E. huxleyi cell density was calculated, taking into account the number of cells viewed, number of SEM fields of view screened, section of filter area scanned, and volume of seawater filtered.

Culturing of Southern Ocean strains. On board the MV 'l'Astrolabe' in March 2006, $50 \mathrm{ml}$ surface water samples were screened immediately after collection,

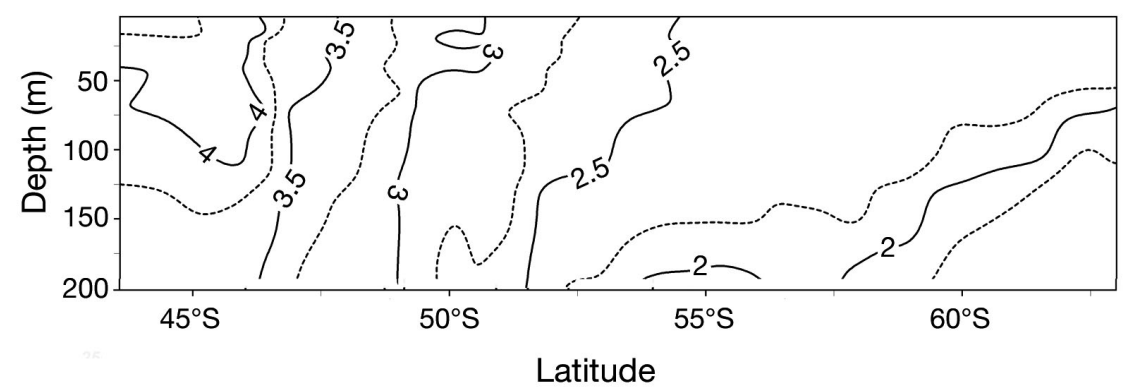

Fig. 2. Calcite saturation status calculated from $\mathrm{TCO}_{2}$ and alkalinity measurements, along a typical 44 to $62^{\circ} \mathrm{S}$ north-south transect occupied by the RV 'Aurora Australis' in November 2001 (Tilbrook et al. 2001). Highly saturated surface water with calcite saturation $>4$ occurs in the north, while surface waters south of $55^{\circ} \mathrm{S}$ typically have values $<2.5$. The steepest gradients in saturation state occur in the transition between the Subantarctic Zone and the North Polar Front through a $20 \mu \mathrm{m}$ plankton net to remove large organisms, and were maintained at $4^{\circ} \mathrm{C}$ in a $50 \mathrm{ml}$ polycarbonate flask topped up with a small amount of Medium K (Keller et al. 1987). One month later, clonal cultures (Culture Codes EHSO-1 to -14) were established from single-cell isolates at the University of Tasmania, using Medium $\mathrm{K}$ at 4 to $15^{\circ} \mathrm{C}$ (depending on the ambient temperature of the sampling site), $35 \mathrm{psu}$ salinity and $100 \mu \mathrm{mol}$ photons $\mathrm{m}^{-2} \mathrm{~s}^{-1}$ of photosynthetically active radiation (PAR).

\section{RESULTS}

Water temperatures along the 43 to $64^{\circ} \mathrm{S}$ northsouth transect ranged from 16 to $0^{\circ} \mathrm{C}$, and salinities from 35.30 to $33.70 \mathrm{psu}$. Carbonate ion concentrations along the cruise track declined from $175 \mu \mathrm{mol} \mathrm{l}^{-1}$ in warm subtropical waters to $95 \mu \mathrm{mol} \mathrm{l}^{-1}$ at the southern end of the transect. Calcite saturation levels calculated from carbon measurements showed a decline in the saturation state from $>4$ in the north to values $<2.5$ south of $55^{\circ} \mathrm{S}$. The steepest gradients in saturation state occurred in the transition between the Subantarctic Zone and the North Polar Front (Fig. 2). The range of calcification morphotypes commonly encountered in the Southern Ocean is illustrated in Fig. 3. Morphotypes shown in Fig. 3a,b,i,j correspond with Type A (var. huxleyi) of Young \& Westbroek (1991) (referred to here as typical Type A) in that the coccoliths possess robust distal shield elements and curved elements in the central area, but the latter are obscured by overcalcification in Fig. 3c,d (hence referred to as Type A 'overcalcified', sensu Young et al. 2003). Morphotypes in Fig. 3e-g,k correspond with Type B/C of Young et al. (2003), in that they possess more delicate distal shield elements and have the central area open or covered by a thin membrane. This same morphotype from the same locality has been previously referred to as Type $\mathrm{C}$ by Findlay \& Giraudeau (2000) and Type K by Hiramatsu \& De Deckker (1996). Distal shield elements of Morphotype A often tended to be straight or concave compared to those of Morphotype B/C, which were convex (compare arrowed coccoliths in Fig. $3 \mathrm{~b}, \mathrm{~g}$ ). The size of coccoliths can vary significantly on the same coccosphere (notably obvious in clonal cultures Fig. 3i-k) and hence was of limited value in discriminating morphotypes. Dissolution morphotypes (in which the coccosphere appears to be partially dissolved; Burns 1977) were rarely observed $(<1 \%$ of total cells). Fig. $3 \mathrm{~h}$ depicts a dissolution form where the distal shield 


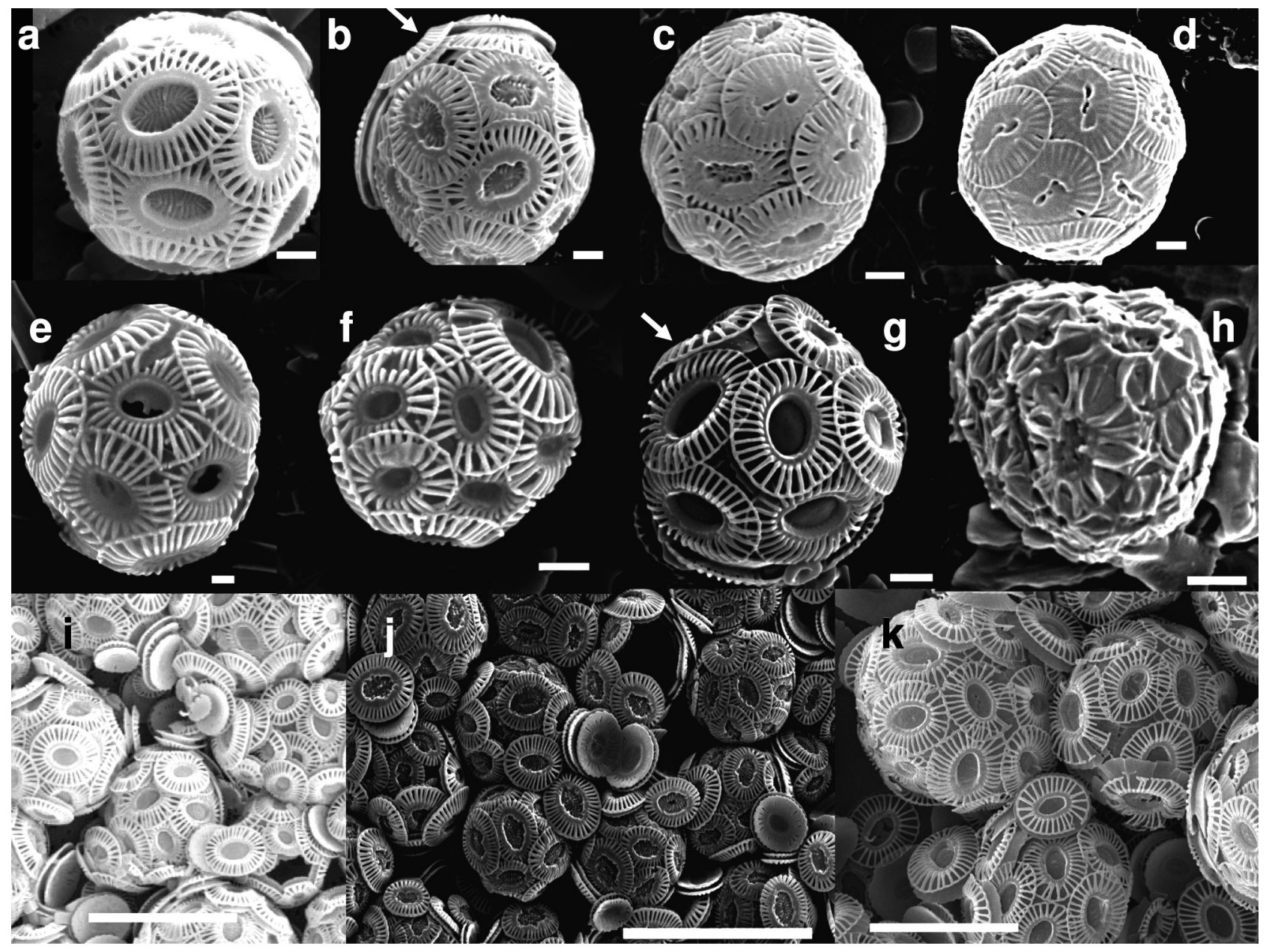

Fig. 3. Emiliania huxleyi. Diversity of morphotypes encountered in Southern Ocean and Australian waters. (a) Typical Type A from Sydney coastal waters. (b) Type A from $45^{\circ} 28^{\prime} \mathrm{S}, 146^{\circ} 93^{\prime} \mathrm{E}$. (c) Type A overcalcified; field sample from $47^{\circ} 04^{\prime} \mathrm{S}, 146^{\circ} 70^{\prime} \mathrm{E}$; 20 October 2004. (d) Type A overcalcified; field sample from $43^{\circ} 72^{\prime} \mathrm{S}, 147^{\circ} 37^{\prime} \mathrm{E}_{\text {; }} 19$ February 2003. (e) Type B/C field sample from $51^{\circ} 79^{\prime} \mathrm{S}, 142^{\circ} 84^{\prime} \mathrm{E}_{;} 4$ April 2006. (f) Type B/C field sample from $55^{\circ} 48^{\prime} \mathrm{S}, 140^{\circ} 73^{\prime} \mathrm{E}$. (g) Type B/C; field sample from $43^{\circ} 74^{\prime} \mathrm{S}, 147^{\circ} 36^{\prime} \mathrm{E}$; 2 March 2006; distal shield elements of Morphotype A often tended to be straight or concave compared to those of Morphotype B/C, which were convex (compare arrowed coccoliths in Panels b and g). (h) Dissolution morphotype; field sample from $59^{\circ} 12^{\prime} \mathrm{S}, 143^{\circ} 04^{\prime} \mathrm{E}$; 24 January 2003. (i-k) Conservation of coccolith morphology in clonal cultures: (i) isolate of Type A from Tasmanian coastal waters; (j) isolate of Type A from 46 $16^{\circ} \mathrm{S}, 146^{\circ} 04^{\prime} \mathrm{E}$; 1 March 2006; (k) isolate of Type B/C from $53^{\circ} 21^{\prime} \mathrm{S}, 1^{\circ} 4^{\circ} 53^{\prime} \mathrm{E} ; 28$ February 2006. Scale bars $=1 \mu \mathrm{m}(\mathrm{a}-\mathrm{h}) ; 10 \mu \mathrm{m}(\mathrm{i}-\mathrm{k})$

elements are almost unrecognizable and only the proximal shield is visible. While the 3 morphotypes (A, A 'overcalcified' and B/C, as originally defined by Young \& Westbroek 1991) were mainly based on the size of the distal shield and the morphology of central area elements, in the Southern Ocean, these morphologies essentially represent a gradient from more to less calcified (Table 1), hence, our terminology of referring to them in the Southern Ocean as being equivalent to 'calcification morphotypes'.

Quantitatively, Emiliania huxleyi is a key species in the Southern Ocean phytoplankton, occurring at cell densities of up to 400 cells $\mathrm{ml}^{-1}$. The dominant morphotype is B/C (Fig. 4), which has never previously been studied in culture and which is distinct from the wellstudied North Atlantic Type A. Morphotype A 'overcalcified' was dominant (60 to $80 \%$ of total E. huxleyi) north of 47 to $48^{\circ} \mathrm{S}$ (roughly the position of the Subantarctic Front), being replaced by the much more weakly calcified dominant Southern Ocean Morphotype B/C from 48 to $65^{\circ} \mathrm{S}$ (ranging down to the Southern Antarctic Circumpolar Current Front). Typical Morphotype A exhibited a partially overlapping distribution from 44 to $55^{\circ} \mathrm{S}$ (roughly from the Subtropical Front to the North Polar Front), but stretched south to $59^{\circ} \mathrm{S}$ in $2004 / 2005$ and contracted again to $50^{\circ} \mathrm{S}$ in 2005/2006 (Figs. 4 \& 5). In all years, Morphotype B/C was the only form of E. huxleyi present south of $57^{\circ} \mathrm{S}$. 
Table 1. Emiliania huxleyi. Morphological variants (sensu Young et al. 2003) identified in the present study. $\mathrm{CaCO}_{3}(\%)$ : percentage of distal shield area covered

\begin{tabular}{|lcccc|}
\hline Morphotype & Distal shield elements & Central area & $\mathrm{CaCO}_{3}(\%)$ & Geographic distribution \\
\hline Type A & $\begin{array}{c}\text { Robust, straight, } \\
\text { or concave } \\
\text { Robust, straight, } \\
\text { or concave } \\
\text { Delicate, convex }\end{array}$ & Elements curved & $50-80$ & $\begin{array}{c}\text { Dominant in Australian } \\
\text { coastal waters }\end{array}$ \\
$\begin{array}{c}\text { Type A } \\
\text { overcalcified }\end{array}$ & $\begin{array}{c}\text { Elements curved; } \\
\text { Irregular laths; open or } \\
\text { covered by thin plain plate }\end{array}$ & $80-95$ & $\begin{array}{c}\text { Dominant in Southern Ocean, } \\
43-47^{\circ} \mathrm{S}\end{array}$ \\
& & $\begin{array}{c}\text { Dominant in Southern Ocean, } \\
\text { south of } 50^{\circ} \mathrm{S}\end{array}$ \\
\hline
\end{tabular}

All cultured isolates from north of the Polar Front belonged to Morphotype A, while all strains isolated south of the Polar Front belonged to Morphotype B/C (Table 2). These differing geographic distributions of E. huxleyi morphotypes in surface samples were also reflected in water column depth distributions down to 100-150 m depth (RV 'Aurora Australis', Voyage 3, November 2001; Fig. 6).

\section{DISCUSSION}

While Emiliania huxleyi was absent or extremely sparse south of $60^{\circ} \mathrm{S}$ in 1983/1984 (Nishida 1986) and 1994/1995 (Findlay \& Giraudeau 2000), this species was consistently present at about 100 cells $\mathrm{ml}^{-1}$ between 60 and $65^{\circ} \mathrm{S}$ during our surveys in the Australian sector of the Southern Ocean from 2002 to 2006. Hasle (1960) first reported the complete absence of E. huxleyi in the Antarctic Pacific based on a grid of stations at 53 to $70^{\circ} \mathrm{S}, 90$ to $174^{\circ} \mathrm{W}$ covered by the 1947 to 1948 Norwegian Brategg Expedition. Thirty-five years later, Nishida (1986) occupied 5 stations, 9 depths each, south of $60^{\circ} \mathrm{S}$ in the same area covered by us, with E. huxleyi being absent or extremely sparse at 0.1 to 1 cells $\mathrm{ml}^{-1}$ (Fig. 1). Another 10 yr later, Findlay \& Giraudeau (2000) occupied 3 stations, 4 depths each, south of $60^{\circ} \mathrm{S}$ in the Australian sector of the Southern Ocean (Fig. 1) and found them to be devoid of E. huxleyi. These observations have led to the dogma of a north-south transition of calcareous towards siliceous nanoplankton (Nishida 1986). Winter et al. (1999) reported E. huxleyi from the Weddell Sea (69 to $71^{\circ} \mathrm{S}$ ) during austral autumn 1992, but suggested that it may have been introduced by the Agulhas Current or a warm eddy system crossing the Brazil-Malvinas confluence into the Antarctic Circumpolar Current. The extended geographic range and increased southward abundance of this keystone species in the Australian sector of the Southern Ocean in the period 2001 to 2006 compared to historic data suggests a significant shift in Southern Ocean ecology over the past 2 decades. This is unlikely to be due to the approxi- mate $0.1^{\circ} \mathrm{C}$ warming of the bulk ocean (Gille 2002), but may reflect enhanced surface warming or changes in zooplankton grazing populations (Atkinson et al. 2004, Hosie 2004) as a result of substantial
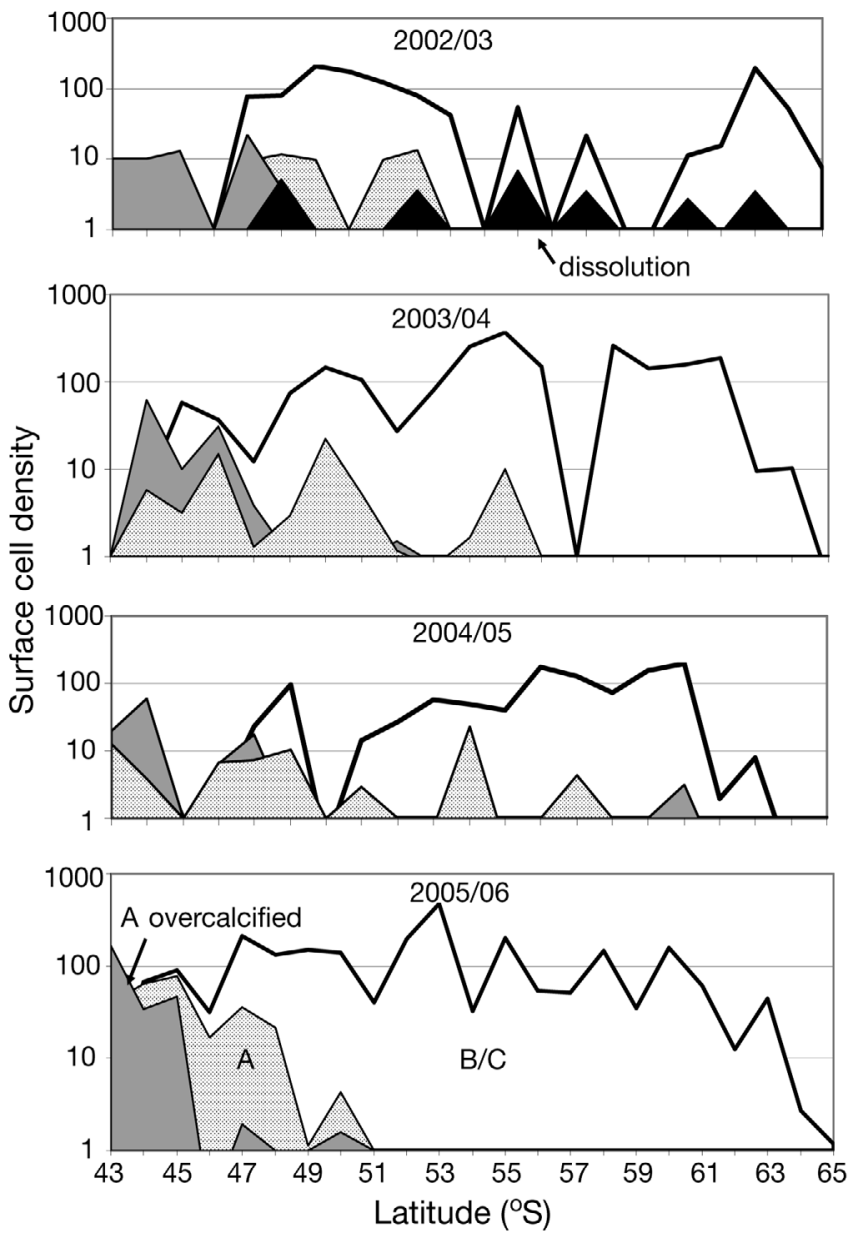

Fig. 4. Emiliania huxleyi. Surface cell density (log cells $\mathrm{ml}^{-1}$ ) of different morphotypes (Types A, A overcalcified and B/C) along a regularly occupied transect in the Southern Ocean from 43 to $66^{\circ} \mathrm{S}$. Cell counts have been averaged on a latitudinal basis for 4 different transects in each October to March period from the years $2002 / 2003$ to $2005 / 2006$. This species was consistently present south of $60^{\circ} \mathrm{S}$, an area from which it was completely absent in previous surveys conducted in 1983/1984 and 1994/1995 


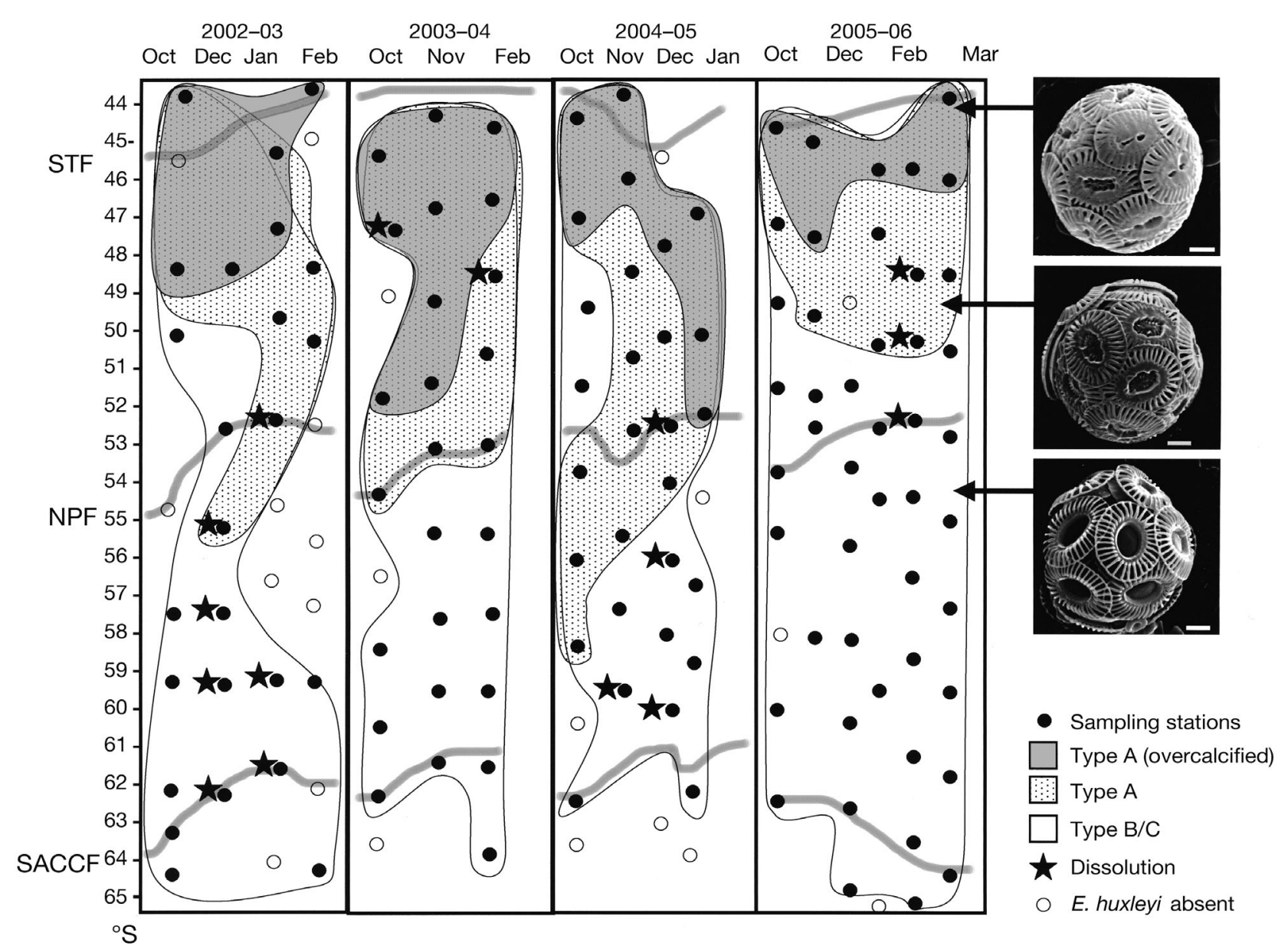

Fig. 5. Emiliania huxleyi. Latitudinal and annual shifts in calcification morphotypes in the Southern Ocean, based on the presence or absence in surface samples collected by the MV 'l'Astrolabe' on a regular transect from 43 to $66^{\circ} \mathrm{S}$ between Tasmania and the Antarctic in 4 consecutive austral summers from 2002/2003 to 2005/2006. Different morphotypes exhibited differing geographic distributions with a distinct southward trend of decreased calcification evident in all years. Subtle yearto-year shifts in distribution patterns of calcification morphotypes are evident, but a full interpretation of their ecological significance awaits genetic and ecophysiological studies on newly established cultured Southern Ocean strains. The approximate positions of the South Tropical Front (STF), the North Polar Front (NPF) and the Southern Antarctic Circumpolar Current Front

(SACCF, both branches) are indicated

retreat of the sea ice zone. We note that an apparently analogous range extension of E. huxleyi has also occurred in the Bering Sea since 1997 (Merico et al. 2003), suggesting that this might be a bipolar phenomenon.

It is likely that the morphotypic variations we observed are genetically based, since these morphologies appear to be conserved in clonal cultures (Fig. 3i-k). Emiliania huxleyi has often been viewed as a single cosmopolitan species, yet considerable evidence now suggests otherwise. Brand (1982) first documented unexpectedly high genetic differentiation in acclimatized growth rates for multiple E. huxleyi clones established from the same water sample. Barker et al. (1994) and Medlin et al. (1996) used randomly amplified polymorphic DNA fingerprints (RAPDs) and amplification fragment length polymorphisms (AFLPs) to reveal exten- sive genetic diversity, both on a global scale and within bloom populations, in both space and time. RAPDs showed that all strains except for 1 pair were genetically distinct, and this appeared to be reflected in their morphology and ecological distribution. Iglesias-Rodriguez et al. $(2002,2006)$ further corroborated a high degree of polymorphism in 87 isolates of different geographical origin using AFLP and microsatellite loci. Preliminary analysis of microsatellite loci in 3 southern hemisphere strains (from Australia, New Zealand, South Africa) has already indicated that they are significantly different from northern hemisphere genotypes (Iglesias-Rodriguez et al. 2006), and we expect even greater genetic distances between Southern Ocean and northern hemisphere strains in molecular studies in progress on our cultured Southern Ocean and Australian strains (Table 2). Studies on E. huxleyi 
Table 2. Emiliania huxleyi. List of Southern Ocean and Australian culture strains established in the present study

\begin{tabular}{|c|c|c|c|c|}
\hline Strain code & No. of strains & Locality & Isolator & Morphotype \\
\hline EHSO2 & 1 & Southern Ocean, $59^{\circ} \mathrm{S}, 143^{\circ} \mathrm{E}$ & de Salas \& Cubillos & $\mathrm{B} / \mathrm{C}$ \\
\hline EHSO3 & 1 & Southern Ocean, $58^{\circ} \mathrm{S}, 143^{\circ} \mathrm{E}$ & de Salas \& Cubillos & $\mathrm{B} / \mathrm{C}$ \\
\hline EHSO4 & 1 & Southern Ocean, $58^{\circ} \mathrm{S}, 143^{\circ} \mathrm{E}$ & de Salas \& Cubillos & $\mathrm{B} / \mathrm{C}$ \\
\hline EHSO5 & 1 & Southern Ocean, $57^{\circ} \mathrm{S}, 144^{\circ} \mathrm{E}$ & de Salas \& Cubillos & $\mathrm{B} / \mathrm{C}$ \\
\hline EHSO6 & 1 & Southern Ocean, $55^{\circ} \mathrm{S}, 144^{\circ} \mathrm{E}$ & de Salas \& Cubillos & $\mathrm{B} / \mathrm{C}$ \\
\hline EHSO8 & 2 & Southern Ocean, $53^{\circ} \mathrm{S}, 145^{\circ} \mathrm{E}$ & de Salas \& Cubillos & $\mathrm{B} / \mathrm{C}$ \\
\hline EHSO10 & 2 & Southern Ocean, $51^{\circ} \mathrm{S}, 146^{\circ} \mathrm{E}$ & de Salas \& Cubillos & $\mathrm{B} / \mathrm{C}$ \\
\hline EHSO11 & 2 & Southern Ocean, $49^{\circ} \mathrm{S}, 146^{\circ} \mathrm{E}$ & de Salas \& Cubillos & A \\
\hline EHSO12 & 1 & Southern Ocean, $46^{\circ} \mathrm{S}, 146^{\circ} \mathrm{E}$ & de Salas \& Cubillos & $\mathrm{A}$ \\
\hline EHSO13 & 1 & Southern Ocean, $46^{\circ} \mathrm{S}, 147^{\circ} \mathrm{E}$ & de Salas \& Cubillos & $\mathrm{A}$ \\
\hline EHSO14 & 1 & Southern Ocean, $45^{\circ} \mathrm{S}, 147^{\circ} \mathrm{E}$ & de Salas \& Cubillos & $\mathrm{A}$ \\
\hline EHMP & 36 & Mercury Passage, Tasmania & de Salas \& Cook & $\mathrm{A}$ \\
\hline EHTB & 81 & Trumpeter Bay, Tasmania & de Salas & In progress \\
\hline EHST & 28 & Stanley, Tasmania & Cook & In progress \\
\hline EHWC & 200 & Western Tasmania & Cook & In progress \\
\hline EHBI & 15 & Bicheno, Tasmania & Cook \& de Salas & In progress \\
\hline EHSB & 15 & Streaky Bay, South Australia & Cook \& de Salas & In progress \\
\hline EHCA & 15 & Cairns, Queensland, Australia & Cook \& de Salas & In progress \\
\hline EHGQ & 9 & Gladstone, Queensland, Australia & Cook & In progress \\
\hline
\end{tabular}

in the North Atlantic have long discriminated between the 2 morphotypes (A and B), which tend to show differing geographic and sometimes depth distributions (Van Bleijswijk et al. 1991, Young \& Westbroek 1991). Schroeder et al. (2005) recently identified a genetic marker that confirmed the genetic basis for discrimination of these North Atlantic morphotypes.

The dominant morphotype in the Southern Ocean is $\mathrm{B} / \mathrm{C}$, which has never previously been studied in culture and which is distinct from the well-studied North Atlantic Type A. Morphotype A 'overcalcified' mainly occurred north of the Subantarctic Front, being replaced by the more weakly calcified Morphotype B/C between the Subantarctic Front and the Southern Antarctic Circumpolar Current Front. This north-south shift in Emiliania huxleyi calcification morphotypes closely tracked the north-south decline in calcite saturation state (Fig. 2). Based on current evidence, no significant changes have become apparent in the calcification status of E. huxleyi in the Southern Ocean during the past 12 yr. All cultured isolates from north of the Polar Front belonged to Morphotype A, while all strains isolated south of the Polar Front belonged to Morphotype B/C, and their morphologies appeared conservative in culture even when grown under a range of environmental conditions (authors' unpubl. data). The north-south trend towards decreasing calcification of E. huxleyi in the Southern Ocean thus reflects a shift in dominance of one ecotype to another, rather than the environmental effect of decreased carbonate ion concentrations and calcite saturation state on a single 'apparently cosmopolitan' population. A similar northsouth trend of calcification morphotypes of E. huxleyi has now also been confirmed for the Indian sector of the Southern Ocean (along a $45^{\circ} \mathrm{E}$ transect; Mohan et al. 2007), while in the northern hemisphere a reverse south-north trend exists off the coast of Japan when moving from the warm Kuroshio to the cold Oyashio Current (Hagino et al. 2005).

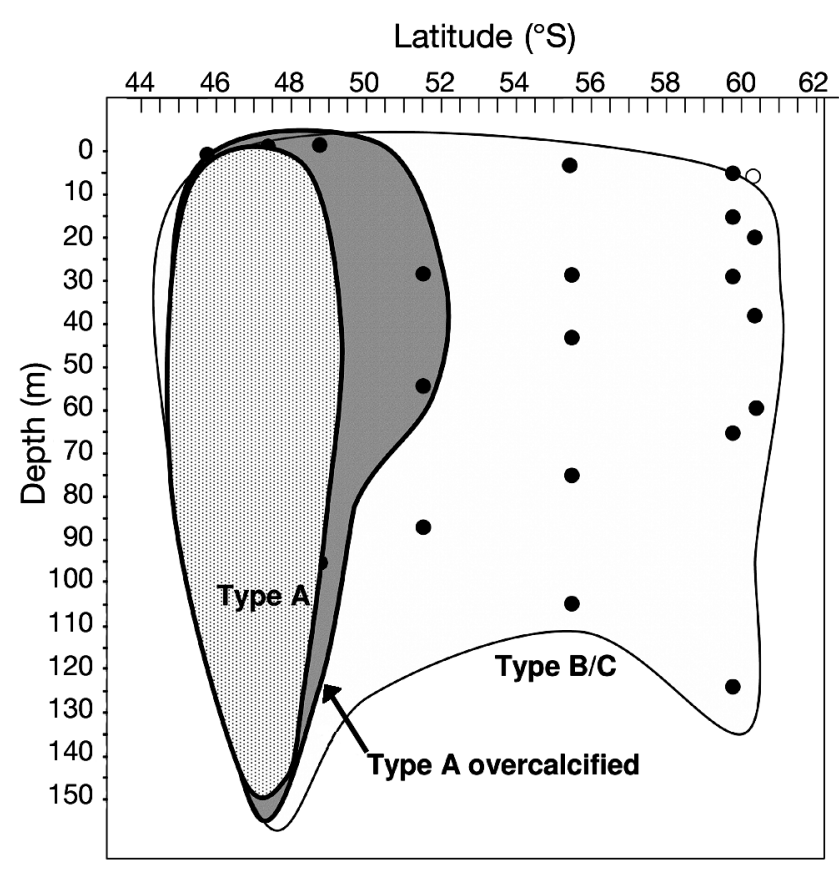

Fig. 6. Emiliania huxleyi. Depth distributions of the presence or absence of 3 different morphotypes along a transect occupied in the Southern Ocean by the Australian RV 'Aurora Australis' in November 2001 (Voyage 3 from 44 to $62^{\circ} \mathrm{S}$ ). Surface distributions of the 3 different morphotypes reflect $150 \mathrm{~m}$ deep water column distributions. O: E. huxleyi absent 
Different Emiliania huxleyi morphologies in the Southern Ocean and in other parts of the world's oceans most likely reflect differing physiological and genetic properties and potentially deserve to be recognized as different varieties. Further studies using robust molecular tools are needed to discriminate between E. huxleyi genotypes in field populations and in culture to improve the confidence of our prediction of the future success of this key ocean plankton. Global extrapolations from research on limited culture strains may produce misleading results due to underestimation of the genetic diversity and ecophysiological plasticity of the plankton superspecies (sensu Thierstein \& Young 2004) E. huxleyi.

Acknowledgements. We thank the captain and crew of MV 'l'Astrolabe' for collaboration in the sampling program. This work was supported by IPSL, INSU and IPEV (France), the Australian Climate Change Reserach Programme, and the Australian Government's Cooperative Research Centres Programme through the Antarctic Climate and Ecosystems Cooperative Research Centre (ACE CRC).

\section{LITERATURE CITED}

Atkinson A, Siegel V, Pakhomov E, Rothery P (2004) Longterm decline in krill stock and increase in salps within the Southern Ocean. Nature 432:100-103

Barker GLA, Green JC, Hayes PK, Medlin LK (1994) Preliminary results using the RAPD analysis to screen bloom populations of Emiliania huxleyi (Haptophyta). Sarsia 79:301-306

Brand L (1982) Genetic variability and spatial patterns of genetic differentiation in the reproductive rates of the marine coccolithophores Emiliania huxleyi and Gephyrocapsa oceanica. Limnol Oceanogr 27:236-245

Burns DA (1977) Phenotypes and dissolution morphotypes of the genus Gephyrocapsa Kamptner and Emiliania huxleyi (Lohmann). NZ J Geol Geophys 20:143-155

Findlay CS, Giraudeau J (2000) Extant calcareous nanoplankton in the Australian Sector of the Southern Ocean (austral summers 1994 and 1995). Mar Micropaleontol 40:417-439

Gille ST (2002) Warming of the Southern Ocean since the 1950s. Science 295:1275-1277

Hagino K, Okada H, Matsuoka H (2005) Coccolithophore assemblages and morphotypes of Emiliania huxleyi in the boundary zone between the cold Oyashio and warm Kuroshio currents off the coast of Japan. Mar Micropaleontol 55:19-47

Hasle GR (1960) Plankton coccolithophorids from the Subantarctic and Equatorial Pacific. Norw J Bot 8:77-88

Hiramatsu C, De Deckker P (1996) Distribution of calcareous nannoplankton near the subtropical convergence, south of Tasmania, Australia. Mar Freshw Res 47:707-713

Hosie G (2004) Southern Ocean CPR survey. Annual report. Sir Alister Hardy Foundation for Ocean Science, Plymouth, p 16-17

Iglesias-Rodriguez MD, Saez AG, Groben R, Edwards KJ, Batley J, Medlin LK, Hayes PK (2002) Polymorphic microsatellite loci in global populations of the marine coccolithophorid Emiliania huxleyi. Mol Ecol Notes 2: 495-497

Iglesias-Rodriguez MD, Schofield OM, Batley J, Medlin LK, Hayes PK (2006) Intraspecific genetic diversity in the marine coccolithophore Emiliania huxleyi (Prymnesio- phyceae): the use of microsatellite analysis in marine phytoplankton population studies. J Phycol 42:526-536

Keller MD, Selvin R, Claus W, Guillard RRL (1987) Media for the culture of oceanic ultraphytoplankton. J Phycol 23: 633-638

Medlin LK, Barker GLA, Campbell L, Green JC, Hayes PK, Marie D, Wrieden S, Vaulot D (1996) Genetic characterisation of Emiliania huxleyi (Haptophyta). J Mar Syst 9:13-31

Merico A, Tyrrell T, Brown CW, Groom SB, Miller PI (2003) Analysis of satellite imagery for Emiliania huxleyi blooms in the Bering Sea before 1997. Geophys Res Lett 30:1337, doi: 10.1029/2002GL016648

Mohan R, Mergulhao LP, Guptha MVS, Rajakumar A, Thamban M, Anil Kumar N, Sudhakar M, Ravindra R (2007) Coccolithophores during the austral summer of 2004 along the $45^{\circ} \mathrm{E}$ transect in the Indian sector of Southern Ocean. Mar Micropaleontol (in press) doi: 110.1016/j.marmicro.2007.08.005

Nishida S (1986) Nanoplankton flora in the Southern Ocean, with special reference to siliceous varieties. Mem Nat Inst Polar Res Spec Issue 40:56-68

Orr JC, Fabry VJ, Aumont O, Bopp L and 24 others (2005) Anthropogenic ocean acidification over the twenty-first century and its impact on calcifying organisms. Nature 437:681-686

Paasche E (2001) A review of the coccolithophorid Emiliania huxleyi (Prymnesiophyceae), with particular reference to growth, coccolith formation and calcification-photosynthesis interactions. Phycologia 40:503-529

Riebesell U, Zondervan I, Rost B, Tortell PD, Zeebe RE, Morel FMM (2000) Reduced calcification of marine plankton in response to increased atmospheric $\mathrm{CO}_{2}$. Nature 407: 364-367

Schroeder DC, Biggi GF, Hall M, Davy J, Martínez JM, Richardson AJM, Malin G, Wilson WH (2005) A genetic marker to separate Emiliania huxleyi (Prymnesiophyceae) morphotypes. J Phycol 41:874-879

Sokolov S, Rintoul ST (2002) Structure of Southern Ocean Fronts at $140^{\circ}$ E. J Mar Syst 37:151-184

The Royal Society (2005) Ocean acidification due to increasing atmospheric carbon dioxide. Available at www. royalsoc.ac.uk (accessed on 1 October 2007)

Thierstein HR,Young J (eds) (2004) Coccolithophores: from molecular processes to global impact. Springer-Verlag, Berlin

Tilbrook B, Rintoul S, Sabine C (2001) Carbon dioxide, hydrographic, and chemical data obtained during the R/V Aurora Australis repeat hydrography cruise in the Southern Ocean: CLIVAR CO2 Repeat Section SR03-2001 (EXPOCODE AA0301), (29 October-22 November 2001). Carbon Dioxide Information Analysis Center, Oak Ridge National Laboratory, US Department of Energy, Oak Ridge, TN

Van Bleijswijk J, Van der Wal P, Kempers R, Veldhuis M, Young JR, Muyzer G, de Vrind-de Jong E, Westbroek P (1991) Distribution of two types of Emiliania huxleyi (Prymnesiophyceae) in the Northeast Atlantic region as determined by immunofluorescence and coccolith morphology. J Phycol 27:566-570

Winter A, Elbrachter M, Krause G (1999) Subtropical coccolithophores in the Weddell Sea. Deep-Sea Res 1 26:439-449

Young JR,Westbroek P (1991) Genotypic variation in the coccolithophorid Emiliania huxleyi. Mar Micropaleontol 18: $5-23$

Young J, Geisen M, Cross L, Kleijne A, Sprengel C, Probert I, Østergaard J (2003) A guide to extant coccolithophore taxonomy. J Nanoplankton Res Spec Issue 1 